\title{
Botryosphaeriaceae Species Associated with Avocado Branch Cankers in California
}

\author{
Virginia McDonald and Akif Eskalen, Department of Plant Pathology and Microbiology, University of California, Riverside 92521
}

\begin{abstract}
McDonald, V., and Eskalen, A. 2011. Botryosphaeriaceae species associated with avocado branch cankers in California. Plant Dis. 95:1465-1473.

Members of the family Botryosphaeriaceae cause branch cankers and dieback on California avocado trees. More intensive pruning, a practice associated with high-density planting that is becoming more common in the California avocado industry, may increase the occurrence of branch canker. This study was undertaken to identify and characterize the Botryosphaeriaceae spp. involved in the branch canker disease complex in order to develop future management strategies. From 2008 to 2009 , branch cankers were sampled from four or five trees from each of eight avocado groves in five California counties. Six Botryo-

sphaeriaceae spp. were identified based on morphology as well as phylogenetic analysis of the internal transcribed spacer region (ITS15.8S-ITS2) and a partial sequence of the $\beta$-tubulin gene. These six species included Neofusicoccum australe, N. luteum, N. parvum, an unknown Neofusicoccum sp., Fusicoccum aesculi, and Dothiorella iberica. Members of the Botryosphaeriaceae were isolated from all avocado-growing regions sampled in California; however, incidence and distribution of species varied. This report is the first description of the isolation of $D$. iberica from avocado branch cankers in California.
\end{abstract}

California accounts for the majority of U.S. avocado production, followed by Florida and Hawaii. In the 2008-09 growing season, the California avocado industry occupied over 64,000 acres and the annual crop was valued at over $\$ 199$ million (2). California avocado fruit are grown year round and a single tree can produce up to $91 \mathrm{~kg}$ of fresh fruit each year, although most average about $27 \mathrm{~kg}$.

Canker on California avocado trees (Persea americana Mill.) can occur on twigs, branches, or trunks and appears to be caused by a complex of fungal species in the family Botryosphaeriaceae $(19,20)$. Pruning wounds can be infection courts of canker pathogens, as well as wounds due to other mechanical injuries and frost damage. Cankers on avocado may exude reddish sap that dries to a whitish-beige powder. Bark may be cracked, darkly discolored, or slightly sunken. On older cankers, bark may be friable and easily removed from the damaged area. Cankered inner bark and wood are red-brown to brown, instead of the normal pale color. In a cross section of a cankered branch, a characteristic wedge-shaped discoloration extending deep into the xylem may be visible. If the xylem is extensively colonized, the affected branch may rapidly wilt, with leaves quickly turning brown but remaining attached (20).

In 1934, Horne described avocado fruit rot as caused by the fungal pathogen in the genus Dothiorella, with fruiting bodies found on dead avocado twigs (15). Because inoculation of healthy twigs did not produce disease, this fungus was not believed to be the cause of branch and twig cankers. He concluded that twig dieback on a tree with heavy foliage was due to shading in competition with other twigs (15). By 1953, Dothiorella gregaria (teleomorph Botryosphaeria ribis) was believed to be the cause of severe trunk cankers at graft unions of avocado on Guatemalan rootstocks (12). Molecular sequencing technology has led to revision of the taxonomy of the family Botryosphaeriaceae $(5,25,28,29)$. New information has revealed that the genus name Dothiorella has been misapplied to anamorphs with hyaline aseptate conidia of the type normally associated with Fusicoccum and Neofusicoccum spp. (7). In addition, it has been shown that similar branch cankers on other woody hosts (e.g., grape and almond) are due to a complex of fun-

Corresponding author: A. Eskalen, E-mail: akif.eskalen@ucr.edu

Accepted for publication 6 July 2011.

doi:10.1094/PDIS-02-11-0136

(C) 2011 The American Phytopathological Society gal species, of which the most common belong to the family Botryosphaeriaceae $(16,36)$.

Members of the Botryosphaeriaceae have a worldwide distribution and cause cankers and fruit rot on a wide variety of woody hosts $(6,8,17,22,27,30,36)$. Species can survive as saprophytes or parasites and some species can survive as endophytes in symptomless tissue (10). Various species within the Botryosphaeriaceae have been isolated from cankers on avocado from many different countries, including Mexico, New Zealand, Peru, South Africa, Chile, Central and South America, Spain, and the United States $(19,20,38)$.

Because the teleomorphs of the Botryosphaeriaceae are rarely seen in nature or in culture, anamorph characteristics have been primarily used for identification $(5,7)$. Using anamorph characteristics combined with DNA sequence data has allowed elucidation of the species involved in branch canker and fruit rot disease complexes. For example, use of morphological and genomic information has led to the recent clarification of the pathogens involved in branch canker in grape (36), mango (30), and almond (16) and fruit rot in olive (17).

For growers to remain competitive in the international market, they must find ways to manage their groves efficiently and significantly increase production. One way to do this is by decreasing spacing between trees from 6 by $6 \mathrm{~m}$ to 3 by $3 \mathrm{~m}$, a practice already employed in Chile and becoming more common in California $(13,14)$. More frequent pruning, such as would occur in a highdensity grove, could increase the dissemination of canker-causing members of the Botryosphaeriaceae from tree to tree, leading to an increase in canker incidence and a possible decrease in yield as cankered branches are pruned out. Identifying and characterizing the primary causal agents of this disease will assist in developing the appropriate control measures to reduce yield loss.

The objective of this study was to identify the species of Botryosphaeriaceae associated with the avocado canker disease complex in California and evaluate their distribution. Morphological and molecular methods were used to characterize these species. Anamorph names will be used for members of the Botryosphaeriaceae family identified in this study.

\section{Materials and Methods}

Field survey and fungal isolation. Between September 2008 and March 2009, four or five symptomatic avocado trees ('Hass') in each of eight avocado groves in five counties (Table 1; Fig. 1) were sampled for Dothiorella canker in order to verify the associ- 
ated Botryosphaeriaceae spp. The groves selected were located in the major avocado production areas in California. Mature trees, at least 10 years old, were sampled for visible branch cankers with depressed and darkly discolored bark. Cankers with active oozing of reddish sap as well as those with dried sap were sampled. Usually, a branch section was cut about 6 in. proximal and distal to the canker and packed on ice for transport back to the lab.

In the laboratory, surface dirt and debris were rinsed off branch samples with deionized water and cankers were photographed. Cankers were surface disinfested with $95 \%$ ethanol and flame sterilized, and the discolored outer bark was cut away. Small pieces of inner bark and xylem tissue from the lesion margins were placed onto $4 \%$ potato dextrose agar (PDA) (Becton, Dickinson and Co., Sparks, MD) amended with tetracycline hydrochloride $(0.01 \%$, $\mathrm{wt} / \mathrm{vol}$ ) (PDA-tet) in 85-mm-diameter petri dishes. Cultures were incubated at room temperature for 3 to 5 days. Pure cultures were

Table 1. Incidence of Botryosphaeriaceae and Phomopsis spp. in the main avocado production areas of California, September 2008 to March 2009

\begin{tabular}{lcccc}
\hline County & Groves $^{\mathbf{a}}$ & $\begin{array}{c}\text { Branch }^{\text {cankers }} \\
\text { can }^{\mathbf{b}}\end{array}$ & $\begin{array}{c}\text { Botryo. spp. } \\
\mathbf{( \% )}^{\mathbf{c}}\end{array}$ & $\begin{array}{c}\text { Phomopsis } \\
\text { spp. (\%) }^{\mathbf{d}}\end{array}$ \\
\hline San Luis Obispo & 2 & 46 & $18(39)$ & $7(15)$ \\
Santa Barbara & 1 & 48 & $18(38)$ & $8(17)$ \\
Ventura & 2 & 71 & $34(48)$ & $3(4)$ \\
Riverside & 2 & 12 & $10(83)$ & $1(8)$ \\
San Diego & 1 & 10 & $2(20)$ & $1(10)$ \\
Total: & 8 & 187 & $82(44)^{\mathrm{e}}$ & $20(11)^{\mathrm{f}}$ \\
\hline
\end{tabular}

${ }^{a}$ Number of groves sampled.

${ }^{\mathrm{b}}$ Number of branch cankers sampled.

${ }^{\mathrm{c}}$ Number of branch cankers (and percentage of the total number of branch cankers sampled per county) yielding Botryosphaeriaceae spp.

${ }^{\mathrm{d}}$ Number of branch cankers (and percentage of the total number of branch cankers sampled per county) yielding Phomopsis spp.

e Total number of branch cankers (and percentage of the total number of branch cankers sampled) yielding Botryosphaeriaceae spp.

${ }^{f}$ Total number of branch cankers (and percentage of the total number of branch cankers sampled) yielding Phomopsis spp. obtained by transferring hyphal tips from the colony margin onto fresh PDA-tet plates. Isolates were stored at $5^{\circ} \mathrm{C}$ as mycelial plugs in 1.5-ml microtubes in $1 \mathrm{ml}$ of sterile deionized water.

Morphological characterization. Twenty-seven Botryosphaeriaceae isolates (Table 2), identified based on sequence data (as described below), were further characterized. Isolates for colony morphological characterization were grown in the dark on PDA-tet agar at $25^{\circ} \mathrm{C}$. In order to obtain conidia, isolates were plated onto $2 \%$ water agar amended with autoclaved pine needles or autoclaved avocado wood chips. Plates were incubated at $25^{\circ} \mathrm{C}$ under a 12-h daily photoperiod for up to 4 weeks to encourage pycnidium formation. Conidial color and shape and presence or absence of septations were noted. The length and width of 50 conidia per isolate were measured using a compound microscope (Olympus BX40 with a Leica DFC420 camera) and the SPOT Imaging Software

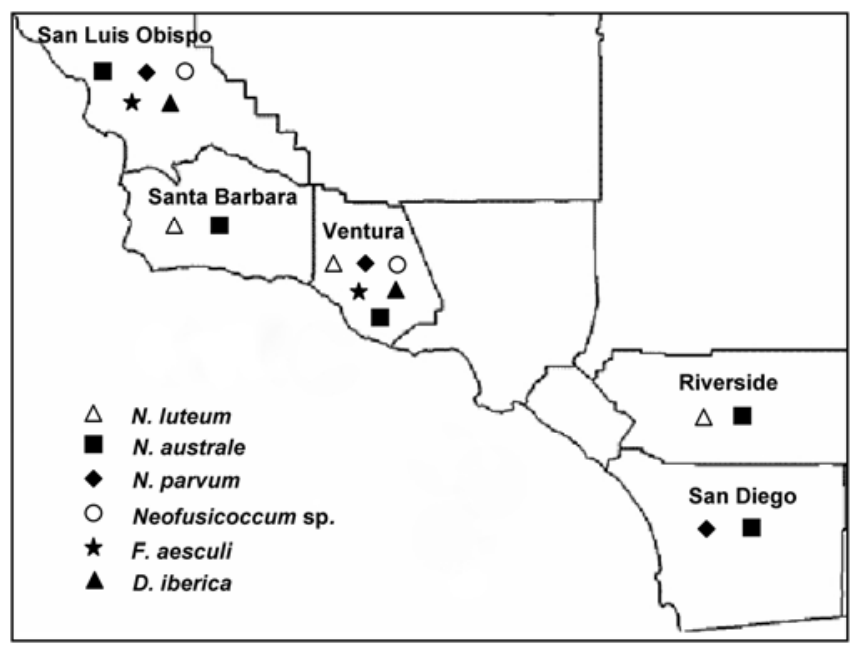

Fig. 1. California counties in which various species of Botryosphaeriaceae were detected in this study.

Table 2. Botryosphaeriaceae isolates from Persea americana in California used in this study

\begin{tabular}{|c|c|c|c|c|c|}
\hline \multirow[b]{2}{*}{ Species $^{\mathrm{a}}$} & \multirow[b]{2}{*}{ Origin $^{b}$} & \multirow[b]{2}{*}{ Collected } & \multirow[b]{2}{*}{ Isolate } & \multicolumn{2}{|c|}{ GenBank number } \\
\hline & & & & ITS $^{c}$ & $\beta$-Tubulin \\
\hline Neofusicoccum australe & Riverside & September 2008 & UCR160 & HQ529741 & HQ529713 \\
\hline$N$. australe & Ventura & November 2008 & UCR508 & HQ529743 & HQ529718 \\
\hline N. australe & Ventura & November 2008 & UCR509 & GQ857659 & GQ857665 \\
\hline N. australe & San Luis Obispo & March 2009 & UCR739 & GQ857662 & GQ857668 \\
\hline N. luteum & Riverside & September 2008 & UCR211 & GQ857658 & GQ857664 \\
\hline$N$. luteum & Ventura & November 2008 & UCR455 & HQ529756 & HQ529726 \\
\hline N. luteum & Ventura & November 2008 & UCR516 & HQ529757 & HQ529727 \\
\hline N. luteum & Santa Barbara & November 2008 & UCR524 & HQ529762 & HQ529732 \\
\hline N. luteum & Santa Barbara & November 2008 & UCR526 & HQ529763 & HQ529733 \\
\hline N. luteum & Ventura & November 2008 & UCR539 & HQ529758 & HQ529728 \\
\hline$N$. luteum & Santa Barbara & November 2008 & UCR594 & HQ529759 & HQ529729 \\
\hline N. luteum & Riverside & September 2008 & UCR654 & HQ529760 & HQ529730 \\
\hline N. parvum & San Diego & October 2008 & UCR295 & HQ529765 & HQ529734 \\
\hline N. parvum & Ventura & November 2008 & UCR531 & GQ857661 & GQ857667 \\
\hline N. parvum & San Luis Obispo & March 2009 & UCR735 & HQ529766 & HQ529735 \\
\hline N. parvum & San Luis Obispo & March 2009 & UCR736 & HQ529767 & HQ529736 \\
\hline N. parvum & San Luis Obispo & March 2009 & UCR737 & GQ857660 & GQ857666 \\
\hline Neofusicoccum sp. & Ventura & November 2008 & UCR468 & HQ529771 & HQ529739 \\
\hline Neofusicoccum sp. & Ventura & November 2008 & UCR532 & HQ529769 & HQ529740 \\
\hline Neofusicoccum sp. & San Luis Obispo & March 2009 & UCR749 & HQ529770 & HQ529738 \\
\hline Fusicoccum aesculi & Ventura & November 2008 & UCR453 & HQ529750 & HQ529721 \\
\hline F. aesculi & Ventura & November 2008 & UCR454 & HQ529751 & HQ529722 \\
\hline F. aesculi & Ventura & November 2008 & UCR652 & GQ857657 & GQ857663 \\
\hline F. aesculi & San Luis Obispo & March 2009 & UCR750 & HQ529752 & HQ529723 \\
\hline Dothiorella iberica & Ventura & November 2008 & UCR452 & HQ529753 & HQ529724 \\
\hline D. iberica & San Luis Obispo & March 2009 & UCR732 & HQ529754 & HQ529725 \\
\hline D. iberica & San Luis Obispo & March 2009 & UCR740 & HQ529755 & HQ529772 \\
\hline
\end{tabular}

a Anamorphs of Botryosphaeriaceae spp. were identified based on morphology and phylogenetic analyses.

${ }^{\mathrm{b}}$ Counties in the state of California in the United States.

c ITS $=$ internal transcribed spacer. 
(v4.7.0.35; Diagnostic Instruments, Inc., MI). Mean and standard deviation of conidial measurements were obtained using summary statistics in SigmaPlot 11.2 (Systat Software Inc., San Jose, CA).

DNA isolation, amplification, and phylogenetic analyses. Total genomic DNA was extracted from each isolate (Table 2) using a modification of the method as described by Cenis (3). Oligonucleotide primers ITS4 and ITS5 were used to amplify the ITS1, ITS2, and 5.8S regions of rDNA (37). A partial sequence of the $\beta$ tubulin nuclear gene was amplified using the $\mathrm{Bt} 2 \mathrm{a}$ and $\mathrm{Bt} 2 \mathrm{~b}$ primers (11). Each $30-\mu$ polymerase chain reaction (PCR) mixture included $20.25 \mu \mathrm{l}$ of PCR-grade water, $3 \mu \mathrm{l}$ of ThermoPol Reaction buffer, $0.6 \mu \mathrm{l}$ of dNTP mix, $2.25 \mu \mathrm{l}$ of each primer, $0.15 \mu \mathrm{l}$ of NEB Taq polymerase, and $1.5 \mu \mathrm{l}$ of DNA template. PCR reactions were carried out in a thermal cycler (Bio-Rad Laboratories, Inc., Hercules, CA) using the following program for both ITS and Bt2 primers: an initial preheat at $94^{\circ} \mathrm{C}$ for $2 \mathrm{~min}$, followed by 25 cycles of denaturation at $94^{\circ} \mathrm{C}$ for $15 \mathrm{~s}$, annealing at $55^{\circ} \mathrm{C}$ for $15 \mathrm{~s}$, and extension at $72^{\circ} \mathrm{C}$ for $45 \mathrm{~s}$. A final extension at $72^{\circ} \mathrm{C}$ was held for 5 min. The PCR products were separated by gel electrophoresis in $1.5 \%$ agarose gels in $1 \times$ Tris-boric acid-EDTA (TBE) buffer and were photographed under UV light after staining with SYBR Green (Invitrogen, Eugene, OR). PCR products were purified using the QIAquick PCR purification kit (Qiagen Inc., Valencia, CA). ITS and $\beta$-tubulin regions were sequenced in both directions at the Institute for Integrative Genome Biology facility of the University of California, Riverside.

Sequences were edited using the program Sequencher 4.6 (Gene Codes Corp., Ann Arbor, MI), locally aligned using ClustalX 2.1Mac OSX (Conway Institute, UCD Dublin) (33), and manually aligned using MacClade 4.08 OSX (Sinauer Associates, Inc., Sunderland, MA) (18). Phylogenetic analysis was completed using PAUP (version 4.0b10; Sinauer Associates; 32). Alignment gaps were treated as missing data. Sequences from isolates obtained in the survey (Table 2) were compared with sequences in GenBank (Table 3) using Guignardia sp. CBS447.68 as the outgroup. Separate and combined analyses were run for the ITS and $\beta$-tubulin data sets. A partition homogeneity test was used to determine whether the ITS and $\beta$-tubulin regions could be combined. Maximum parsimony analysis was performed using the heuristic search option (NNI branch swapping). Bootstrap values were evaluated using
1,000 replicates and 100 random sequence additions to test branch strength. Tree length, consistency index (CI), retention index (RI), rescaled consistency index (RC), and homoplasy index (HI) were recorded for all analyses.

\section{Results}

Field survey and morphological characterization. Cankers on trees in avocado groves were mostly on branches, characterized by darkened and depressed areas of bark, and sometimes oozed reddish sap. On older cankers, the bark was easily removed, and a dried, white powder exudate was frequently present. In the xylem tissue, cankers were reddish-brown in color and variable in shape. Branch cross sections revealed that some discoloration extended into the center with a characteristic wedge shape. Dieback of the affected branch also was usually present.

Botryosphaeriaceae spp. were present in all eight groves sampled and were isolated from 82 of 187 cankers (Table 1). Members of the Botryosphaeriaceae were the most abundant fungi isolated from avocado branch cankers in California, followed by Phomopsis spp. (Table 1). Other sporadically isolated fungi from avocado branch cankers were identified as belonging to the genera Bionectria, Colletotrichum, Schizophyllum, Fusarium, Eutypella, and Phaeoacremonium, based on morphological and DNA sequence evidence.

There were five distinct groups of Botryosphaeriaceae isolates based on colony color and growth characteristics. The first group had buff-colored, aerial hyphae in patchy tufts that covered the surface of the medium in an $85-\mathrm{mm}$ petri plate in 2 to 3 days, with some isolates growing up the sides of the plate. Isolates in this group had either very pale yellow to bright yellow pigment in the center on the reverse of the plate, which is characteristic of Neofusicoccum australe and Neofusicoccum luteum $(22,29)$. With age, the reverse of the colony became a progressively darker greenish-gray color, with the top of the culture showing dense hyphae that were appressed in the middle but fluffier at the margin. By day 9 to 10, the reverse of the colony was completely black, with the top of the culture showing moderate to dense, appressed hyphae with color varying from light to very dark gray-black. Conidial morphology and DNA analyses (below) were used to identify the two species in this group as N. australe (Slippers, Crous \& M.J.

Table 3. Sequences from GenBank used in the phylogenetic study

\begin{tabular}{|c|c|c|c|c|c|}
\hline \multirow[b]{2}{*}{ Isolate $^{a}$} & \multirow[b]{2}{*}{ Species } & \multirow[b]{2}{*}{ Host } & \multirow[b]{2}{*}{ Origin } & \multicolumn{2}{|c|}{ GenBank number } \\
\hline & & & & ITS $^{\mathbf{b}}$ & $\beta$-Tubulin \\
\hline UCD1314So & Neofusicoccum australe & Vitis vinifera & California & DQ008323 & DQ008346 \\
\hline UCD1467So & N. australe & $V$. vinifera & California & DQ233610 & DQ233631 \\
\hline CMW6837 & N. australe & Acacia sp. & Australia & AY339262 & AY339254 \\
\hline UCD2057Te & N. luteum & $V$. vinifera & California & DQ233604 & DQ233625 \\
\hline UCD2089Te & N. luteum & $V$. vinifera & California & DQ233605 & DQ233626 \\
\hline UCD2090Te & N. luteum & $V$. vinifera & California & DQ233606 & DQ233627 \\
\hline CMW9076 & N. luteum & Malus $\times$ domestica & New Zealand & AY236946 & AY236922 \\
\hline CMW10310 & N. luteum & $V$. vinifera & Portugal & AY339259 & AY339251 \\
\hline UCD642So & N. parvum & $V$. vinifera & California & DQ008328 & DQ008351 \\
\hline UCD646So & N. parvum & $V$. vinifera & California & DQ008329 & DQ008352 \\
\hline UCD759St & N. parvum & $V$. vinifera & California & DQ233611 & DQ233632 \\
\hline CMW7798 & N. parvum & Magnifera indica & Australia & AY615183 & AY615170 \\
\hline CMW7799 & N. parvum & Persea americana & Australia & AY615184 & AY615171 \\
\hline PD283 & N. arbuti & Arbutus menziesii & United States & GU251154 & GU251814 \\
\hline PD284 & N. arbuti & A. menziesii & United States & GU251153 & GU251813 \\
\hline PD301 & N. nonquaesitum & Vaccinium sp. & Chile & GU251164 & GU251824 \\
\hline PD302 & N. nonquaesitum & Vaccinium sp. & Chile & GU251165 & GU251825 \\
\hline CMW8000 & Fusicoccum aesculi & Prunus sp. & Switzerland & AY236949 & AY236927 \\
\hline SDAU07164 & F. aesculi & Punica granata & China & FJ171720 & FJ238529 \\
\hline SDAU08.56 & F. aesculi & Populus sp. & China & FJ214104 & FJ238527 \\
\hline UCD1439SLO & Dothiorella iberica & V. vinifera & California & EF202008 & EF202015 \\
\hline UCD1448SLO & D. iberica & $V$. vinifera & California & EF202009 & EF202016 \\
\hline CBS 113188 & D. iberica & Quercus suber & Spain & AY573198 & EU673097 \\
\hline CBS447.68 & Guignardia philoprina & Taxus baccata & The Netherlands & FJ824768 & FJ824779 \\
\hline
\end{tabular}

a Acronyms of culture collections: UCD = University of California, Davis; CMW = Culture Collection Forestry and Agricultural Biotechnology Institute,

University of Pretoria, South Africa; SDAU = Shandong Agricultural University; CBS = Centraalbureau Schimmelcultures, Utrecht, The Netherlands.

b ITS = internal transcribed spacer. 
Wingf.) Crous, Slippers \& A.J.L. Phillips and N. luteum (Pennycook \& Samuels) Crous, Slippers \& A.J.L. Phillips (9).

Colonies of the second group had gray-white, dense, fluffy, aerial mycelium, with the reverse of the colony showing a dark greenish center becoming light green-gray and then white at the edges. The colony covered the entire medium surface by about day 3 . By day 10 , the reverse of the culture was dark green-gray to black and the upper surface of the culture showed dense appressed dark gray hyphae with scattered aerial light gray to white tufts. Conidial morphology and DNA analyses (below) were used to identify these isolates as Neofusicoccum parvum (Pennycook \& Samuels) Crous, Slippers \& A.J.L. Phillips (9).

Isolates of the third group had white to light gray, thin, fluffy hyphae and covered the surface of the medium by day 4. By day 10 , the upper surface of the colonies were light to medium-dark gray to black with dense, appressed hyphae and with scattered whitish tufts, and were less dense near the center. The reverse of the plate was dark green-black. Conidial morphology and DNA analyses (below) were used to identify these isolates as Fusicoccum aesculi Corda (9).

The fourth group had white-gray to light yellow, dense, cottony mycelium that covered the surface of the medium by day 4 to 5 . The reverse varied from white-beige to light yellow with a dark greenish-gray center. By day 10, the surface of the colony showed scattered patches of dark green-gray hyphae, usually whiter at the edges. The reverse showed variable patches of color from whitish beige to yellow to green-gray. By day 15, the dark green-gray areas were converging, with patchy whitish edges. Conidial morphology and DNA analyses (below) closely group these isolates with a recently described species, Neofusicoccum nonquaesitum, but which will be referred to as Neofusicoccum sp. in this article.

The fifth group had thin white or gray or brown hyphae, slightly fluffy, almost to the edge of the plate by day 7 . By day 10 , the upper surface showed thin to moderately dense, appressed hyphae, with color ranging from light to dark green-gray to brown, with buff edges. The reverse of the plate showed dark green-black hyphae with buff outer edges. Conidial morphology and DNA analyses (below) were used to identify these isolates as Dothiorella iberica A.J.L. Phillips, J. Luque \& A. Alves (9).

Conidial characteristics separated the Botryosphaeriaceae family into two groups. The first group consisted of five of the six species noted above ( $N$. australe, N. luteum, N. parvum, Neofusicoccum sp., and $F$. aesculi), with conidia that were hyaline and thin walled. The other group consisted of one species (D. iberica), with conidia that were pigmented and thick walled. The conidial measurements obtained for these Botryosphaeriaceae spp. in California are shown in Table 4, along with previously reported measurements (16,22-24,29).

Phylogenetic analyses. Of the 613 ITS sequence nucleotides analyzed, 72 were parsimony informative. Maximum parsimony analysis of the ITS region resulted in one most-parsimonious tree (length $=183, \mathrm{CI}=0.809, \mathrm{RI}=0.946, \mathrm{RC}=0.765$, and $\mathrm{HI}=$ 0.191; Fig. 2). The ITS tree contained two major clades, the first of which (100\% bootstrap support) was resolved into one group corresponding to F. aesculi. The second major clade (77\% bootstrap support) was resolved into two subclades. The first subclade (74\% bootstrap support) corresponded to species with Neofusicoccum anamorphs, and this was resolved further into N. luteum, $N$. australe, $N$. parvum, and one Neofusicoccum sp. closely related to $N$. nonquaesitum. The second subclade (100\% bootstrap support) corresponded to $D$. iberica.

Of the $484 \beta$-tubulin sequence nucleotides analyzed, 100 were parsimony informative. Maximum parsimony analysis of the $\beta$ tubulin region resulted in one most-parsimonious tree (length $=$ $233, \mathrm{CI}=0.841, \mathrm{RI}=0.955, \mathrm{RC}=0.804$, and $\mathrm{HI}=0.159$; Fig. 3). This tree contained two major clades, the first of which $(100 \%$ bootstrap support) corresponded to D. iberica. The second major clade ( $84 \%$ bootstrap support) resolved into two subclades. The first subclade $(72 \%)$ corresponded to $N$. luteum, $N$. australe, $N$. parvum, and one Neofusicoccum sp. closely related to N. nonquaesitum. The second subclade (100\% bootstrap support) corresponded to $F$. aesculi. Also noted is the reversal of the placement of the $F$. aesculi clade with the $D$. iberica clade in the $\beta$-tubulin tree.

A partition homogeneity test indicated that the ITS and $\beta$-tubulin datasets could be combined $(P=0.33)$. Of the 1,095 nucleotides analyzed, 172 were parsimony informative. Maximum parsimony analysis yielded one most-parsimonious tree (length $=416, \mathrm{CI}=$ $0.824, \mathrm{RI}=0.950, \mathrm{RC}=0.783$, and $\mathrm{HI}=0.175$ ). The topology of this tree (Fig. 4) was consistent with the topology of the ITS tree (Fig. 2). Two major clades were resolved, the first of which (100\% bootstrap support) corresponded to $F$. aesculi. The second major clade (77\% bootstrap support) was resolved into two subclades. The first subclade (72\% bootstrap support) corresponded to $N$.

Table 4. Conidial measurements of Botryosphaeriaceae fungi from California used in this study and comparison with previous studies

\begin{tabular}{|c|c|c|c|c|}
\hline \multirow[b]{2}{*}{ Species, isolate } & \multicolumn{2}{|c|}{ Botryosphaeriaceae spp. in this study } & \multirow{2}{*}{$\begin{array}{c}\text { Botryosphaeriaceae spp. from previous studies } \\
\text { Conidial size }(\mu \mathrm{m})^{\mathrm{c}}\end{array}$} & \multirow[b]{2}{*}{ Source } \\
\hline & Conidial size $(\mu \mathrm{m})^{\mathbf{a}}$ & Mean \pm SD $(\mu \mathrm{m})^{\mathbf{b}}$ & & \\
\hline \multicolumn{5}{|c|}{ Neofusicoccum australe } \\
\hline UCR508 & $(15-) 19-21 \times(6-) 7-8$ & $18.9 \pm 1.2 \times 6.9 \pm 0.4$ & $(18-) 23-26(-30) \times 5-6(-7.5)$ & 29 \\
\hline UCR509 & $(13-) 22-27 \times(5-) 7-8$ & $21.8 \pm 3.4 \times 7.0 \pm 1.0$ & $\ldots$ & $\ldots$ \\
\hline UCR745 & $(12-) 19-23 \times(5-) 7-8$ & $19.3 \pm 1.8 \times 7.2 \pm 0.9$ & $\ldots$ & $\ldots$ \\
\hline \multicolumn{5}{|l|}{ N. luteum } \\
\hline UCR444 & $(20-) 27-34 \times(6-) 7-8$ & $27.4 \pm 2.9 \times 6.9 \pm 0.6$ & $(14-) 20-24(-32) \times(5-) 6-7(-9)$ & 22 \\
\hline UCR516 & $(17-) 21-24 \times(7-) 7-8$ & $20.7 \pm 1.7 \times 7.3 \pm 0.5$ & $(15-) 18-22.5(-24) \times 4.5-6(-7.5)$ & 23 \\
\hline \multicolumn{5}{|l|}{ N. parvum } \\
\hline UCR295 & $(9-) 16-22 \times(5-) 7-8$ & $15.4 \pm 2.6 \times 6.5 \pm 0.6$ & $(11-) 14-18(-23) \times 5-7(-10)$ & 22 \\
\hline UCR531 & $(17-) 20-22 \times(6-) 6-7$ & $19.9 \pm 1.1 \times 6.4 \pm 0.5$ & $(12-) 15-20(-24) \times(4-) 4.5-6(-7.5)$ & 23 \\
\hline UCR736 & $(12-) 17-20 \times(6-) 7-8$ & $16.9 \pm 1.5 \times 7.1 \pm 0.6$ & $\ldots$ & $\ldots$ \\
\hline Neofusicoccum sp. & & & N. nonquaesitum & 16 \\
\hline UCR532 & $(13-) 20-26 \times(6-) 7-8$ & $19.8 \pm 2.8 \times 6.7 \pm 0.5$ & $(17.2-) 23.2 \pm 2.7(-29.1) \times(5.6-) 7.6 \pm 1.0(-10.6)$ & \\
\hline UCR749 & $(20-) 24-31 \times(6-) 7.5-9$ & $24.2 \pm 2.2 \times 7.4 \pm 0.8$ & $\ldots$ & $\ldots$ \\
\hline \multicolumn{5}{|l|}{ Fusicoccum aesculi } \\
\hline UCR454 & $(21-) 23-28 \times(6-) 7-8$ & $23.4 \pm 1.5 \times 6.9 \pm 0.4$ & $(15-) 20-26(-32) \times(4-) 5-6(-9)$ & 22 \\
\hline UCR652 & $(21-) 26-32 \times(6-) 7-9$ & $25.8 \pm 2.2 \times 7.2 \pm 0.7$ & $(18-) 21-28.5-(-30) \times(3.5-) 4-4.5(-6)$ & 23 \\
\hline UCR750 & $(11-) 21-26 \times(4-) 6-8$ & $20.6 \pm 2.5 \times 6.2 \pm 0.7$ & $\ldots$ & $\ldots$ \\
\hline \multicolumn{5}{|l|}{ Dothiorella iberica } \\
\hline UCR452 & $(17-) 24-30 \times(11-) 14-19$ & $23.8 \pm 2.2 \times 13.9 \pm 1.5$ & $(17.2-) 23-23.4(-28.6) \times(8.1-) 10.8-11(-16)$ & 24 \\
\hline UCR681 & $(19-) 24-26 \times(9-) 10-11$ & $23.5 \pm 1.3 \times 9.9 \pm 0.6$ & $\ldots$ & $\ldots$ \\
\hline UCR732 & $(22-) 24-27 \times(8-) 10-12$ & $24.2 \pm 1.2 \times 9.8 \pm 0.7$ & $\ldots$ & $\ldots$ \\
\hline
\end{tabular}

${ }^{a}$ Minimum size, mode, and maximum size in length and width of 50 conidia from each isolate.

${ }^{\mathrm{b}} \mathrm{SD}=$ standard deviation.

${ }^{\mathrm{c}}$ Minimum size, most common values, and maximum size for length and width of conidia. 
luteum, N. australe, N. parvum, and one Neofusicoccum sp. closely related to $N$. nonquaesitum. The second subclade (100\% bootstrap support) corresponded to D. iberica.

Distribution of Botryosphaeriaceae spp. in California. At least two Botryosphaeriaceae spp. were found in all counties sampled in this study (Table 5; Fig. 1). N. luteum was the species most frequently isolated from cankers, followed by $N$. australe, $F$. aesculi, N. parvum, D. iberica, and Neofusicoccum sp. Not all species were found in all counties. $N$. australe was found in all five counties. N. luteum was found in all counties, except for Riverside County. N. parvum was found in San Luis Obispo and Ventura
Counties, in addition to the southern county of San Diego. F. aesculi, D. iberica, and the unknown Neofusicoccum sp. were found only in the two northern counties of San Luis Obispo and Ventura (Table 5; Fig.1).

\section{Discussion}

This study represents the first attempt to determine the presence and diversity of Botryosphaeriaceae fungi associated with avocado branch canker in the major avocado production areas of California. Six different Botryosphaeriaceae spp. were isolated from avocado branch cankers. The diversity of species present is similar to that

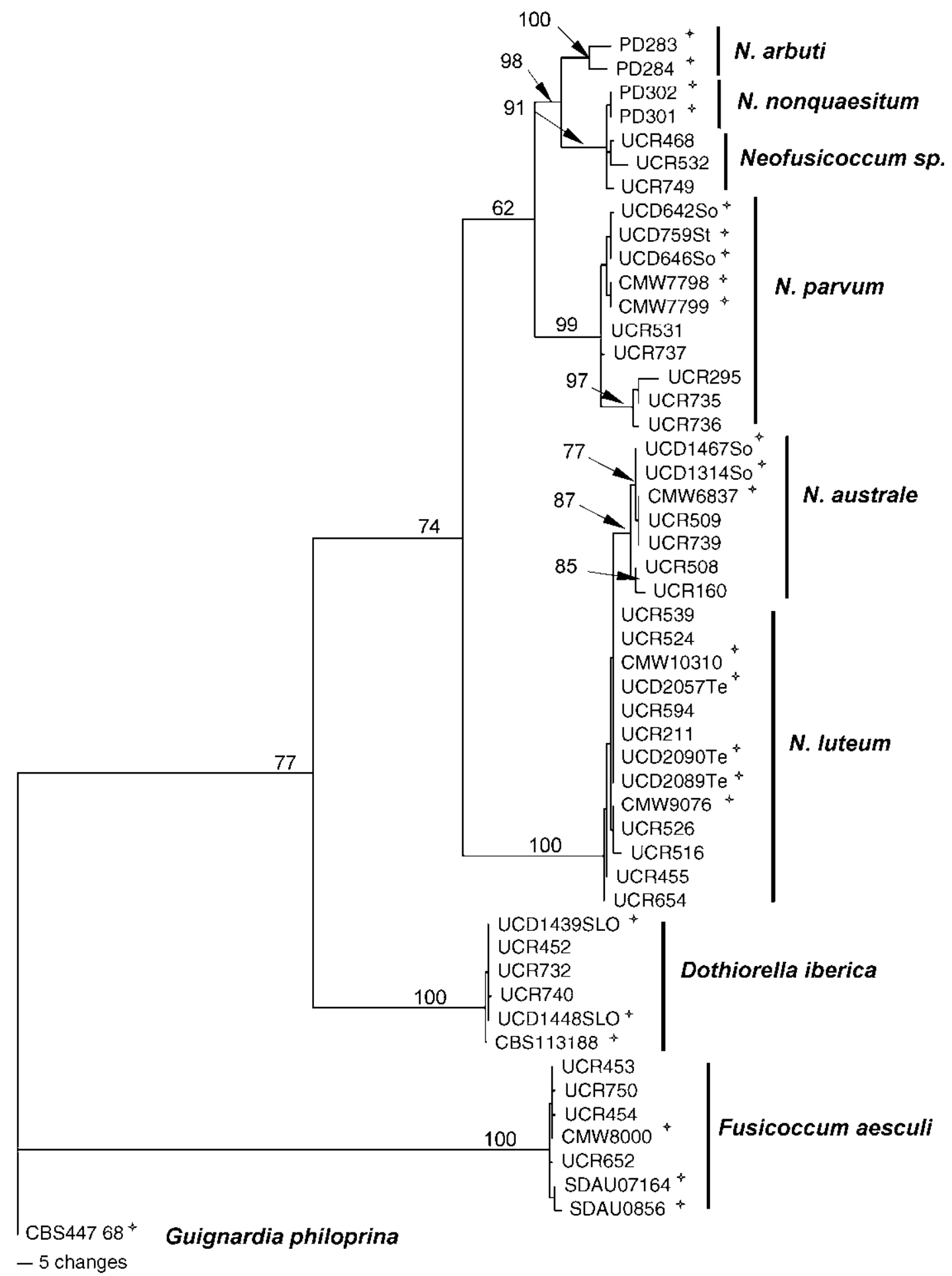

Fig. 2. Most equally parsimonious tree with bootstrap values obtained from the internal transcribed spacer (ITS)1, 5.8S rDNA region, and ITS2 sequence data using 1,000 replicates generated in PAUP. Asterisks show GenBank reference sequences. The anamorph of each Botryosphaeriaceae member is shown, except for the outgroup, which is named by its teleomorph. 
reported on other woody hosts in California $(1,16,36)$ as well as other parts of the world $(8,26,27,31)$. A previous study confirmed that the most abundant Botryosphaeriaceae spp. isolated in this study (N. luteum, N. parvum, $N$. australe, and $F$. aesculi) caused disease of avocado in California (19). A preliminary study has also shown D. iberica and the Neofusicoccum sp. to cause disease on avocado (data not shown).

The resulting ITS and combined ITS and $\beta$-tubulin phylogenetic trees from our study are consistent with results of other recent research that differentiated the anamorphs of the Fusicoccum and Neofusicoccum clades based on the 28S rRNA gene and hyaline, thin-walled conidial morphology (5) and the Dothiorella clade based on the ITS and EF1- $\alpha$ genes and pigmented, thick-walled conidial morphology (24). However, our phylogenetic analysis based on the $\beta$-tubulin gene sequences shows the placement of the $F$. aesculi clade reversed with the $D$. iberica clade, for reasons which are unclear at this time. Recent work to resolve the placement of the dark-spored genera in the Botryosphaeriaceae family clearly shows $D$. iberica as the sister clade to the Neofusicoccum clade (25), as shown in our ITS and combined trees, and as noted in more detail below.

To our knowledge, this article is the first to report on the isolation of $D$. iberica from avocado branch cankers in California. D. iberica has been isolated from cankers on grapevine in

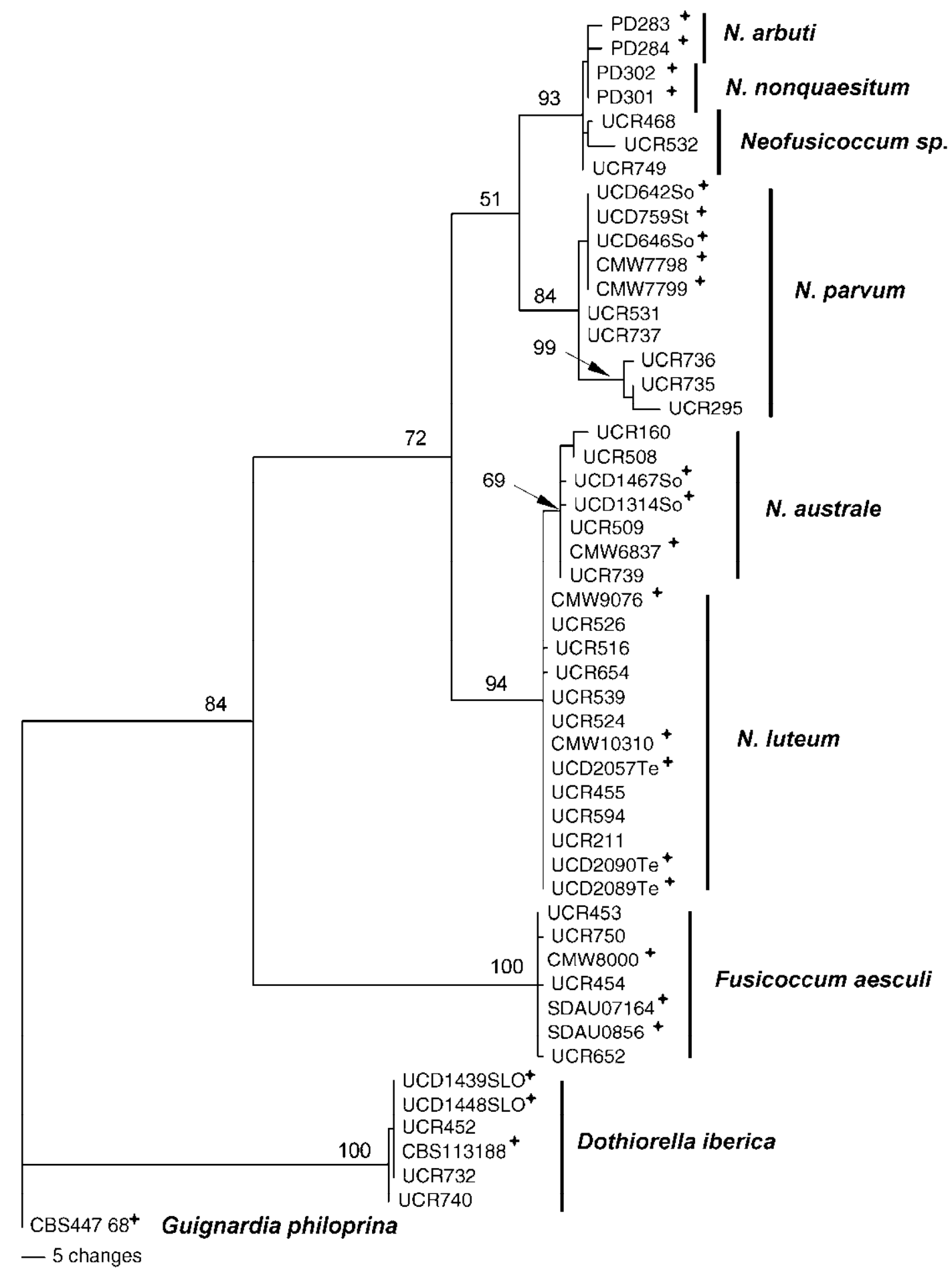

Fig. 3. Most equally parsimonious tree with bootstrap values obtained from the partial $\beta$-tubulin gene sequence data using 1,000 replicates generated in PAUP. Asterisks show GenBank reference sequences. The anamorph of each Botryosphaeriaceae member is shown, except for the outgroup, which is named by its teleomorph. 
California (35). The genus name Dothiorella has been the source of much confusion in the past because it has been used in more than one sense. Although avocado branch canker has been known (34) as Dothiorella branch or stem canker and Dothiorella fruit rot, this nomenclature is outdated for two reasons. First, as has been noted here and elsewhere $(30,36)$, cankers of woody hosts are caused by a number of species in the Botryosphaeriaceae and are not limited to the genus Dothiorella. Second, the genus name of Dothiorella for branch canker was misapplied by Petrak in 1922, according to Denman (7). Petrak was the first to make the connection between the teleomorph Botryosphaeria and the anamorph Fusicoccum, but Petrak referred to Fusicoccum, which has hyaline, thin-walled spores, as Dothiorella, which has pigmented, thick-walled spores, leading to a long period of misapplication of the name Dothiorella (7). In 1999, Crous and Palm synonymized Dothiorella with Diplodia (4). However, Phillips subsequently separated Dothiorella from Diplodia based on two fungal isolates which, on phylogenetic analysis (ITS + EF1- $\alpha$ ), fell within the Fusicoccum clade, but were morphologically distinct from Fusicoccum spp. and could not be

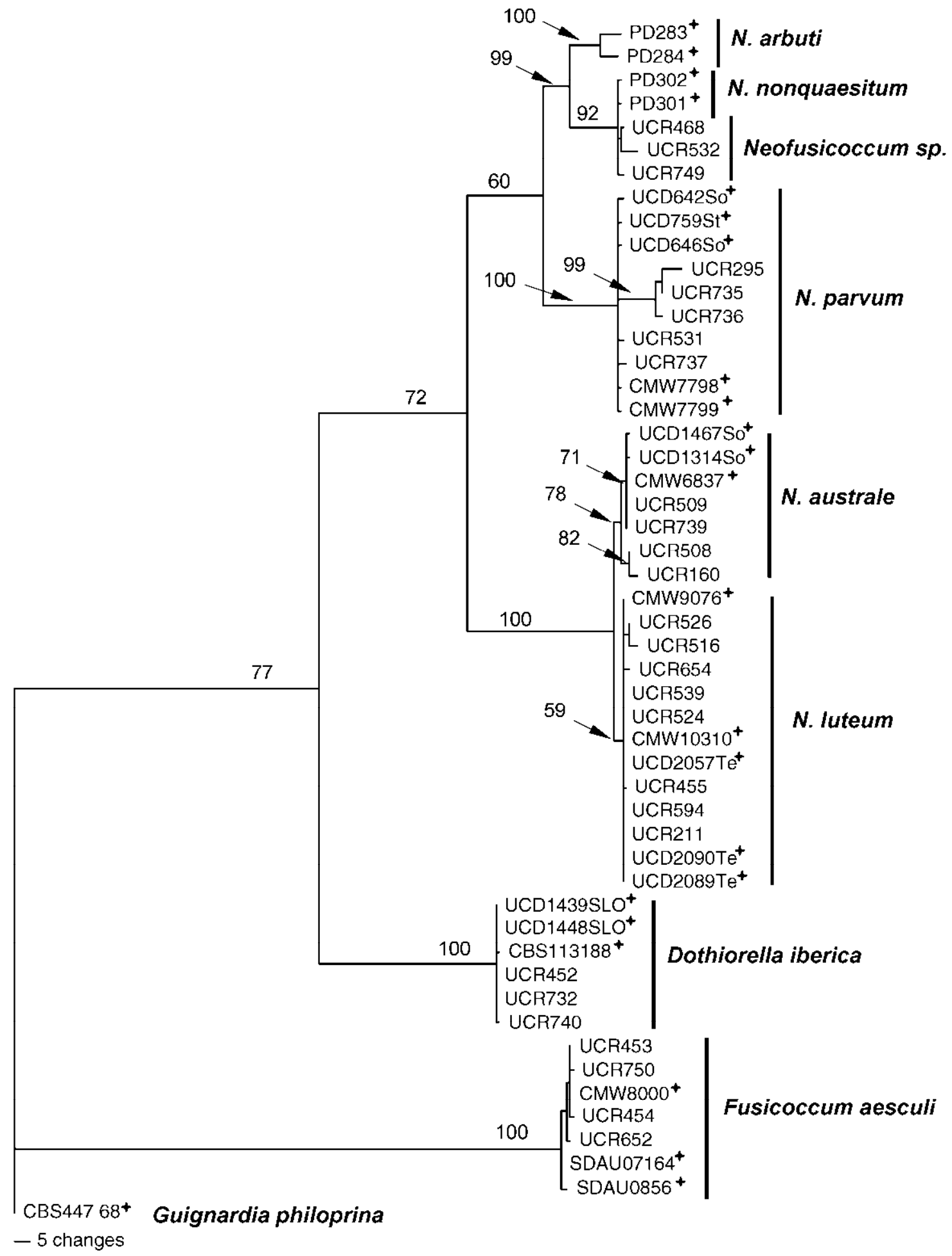

Fig. 4. Most equally parsimonious tree with bootstrap values obtained from the internal transcribed spacer (ITS)1, 5.8S rDNA region, ITS2, and partial $\beta$-tubulin gene sequence data using 1,000 replicates generated in PAUP. Asterisks show GenBank reference sequences. The anamorph of each Botryosphaeriaceae member is shown, except for the outgroup, which is named by its teleomorph. 
Table 5. Number of each Botryosphaeriaceae spp. and average air temperature, by county, in the main avocado production areas of California, September 2008 to March 2009

\begin{tabular}{|c|c|c|c|c|c|c|c|}
\hline County & $\begin{array}{l}\text { Neofusicoccum } \\
\text { australe }\end{array}$ & N. luteum & N.parvum & $\begin{array}{c}\text { Unknown } \\
\text { Neofusicoccum sp. }\end{array}$ & $\begin{array}{l}\text { Fusicoccum } \\
\text { aesculi }\end{array}$ & $\begin{array}{l}\text { Dothiorella } \\
\text { iberica }\end{array}$ & $\begin{array}{c}\text { Temperature } \\
\left({ }^{\circ} \mathbf{C}\right)^{\mathrm{a}}\end{array}$ \\
\hline San Luis Obispo & 8 & 0 & 4 & 1 & 3 & 2 & 13.1 \\
\hline Santa Barbara & 1 & 17 & 0 & 0 & 0 & 0 & 15.0 \\
\hline Ventura & 13 & 9 & 1 & 2 & 8 & 1 & 16.4 \\
\hline Riverside & 3 & 7 & 0 & 0 & 0 & 0 & 18.2 \\
\hline San Diego & 1 & 0 & 1 & 0 & 0 & 0 & 15.8 \\
\hline Total & 26 & 33 & 6 & 3 & 11 & 3 & $\ldots$ \\
\hline
\end{tabular}

a Average air temperature, March 2008 to March 2009.

accommodated in this clade (24). Therefore, he placed these two species in the resurrected genus Dothiorella as D. sarmentorum and D. iberica (24). In 2008, a multigene approach (SSU, LSU, ITS, $\beta$-tubulin, and EF1- $\alpha$ ) was used to further resolve the taxonomy and phylogeny of the dark-spored Botryosphaeria-like teleomorphs and their associated anamorphs (25). The result of this study, in regards to Dothiorella, shows the Dothiorella clade to be more closely related to the Neofusicoccum clade than to the Fusicoccum clade. Phillips et al. (25) also proposed that the anamorph genus name Dothiorella be used for both the anamorph and teleomorph of this clade.

The Neofusicoccum sp. closely related to N. nonquaesitum cannot be definitively identified as such at this time based on the following considerations. This group was based on two DNA loci of only three total isolates obtained from San Luis Obispo and Ventura Counties from a single host species. In contrast, Inderbitzin et al. (16), in identifying the $N$. nonquaesitum species, used six DNA loci on 132 isolates from 36 plant hosts from five continents. They found that 12 species of Fusicoccum and Neofusicoccum have conidial dimensions similar to $N$. nonquaesitum. In addition, although our three isolates were within the same terminal clade as the $N$. nonquaesitum sequences from GenBank, our isolates grouped separately from them. Further analysis of these isolates using additional loci would clarify the identity of these isolates.

There was intraspecific genetic variation noted in every terminal clade, except for $D$. iberica. The intraspecific variation noted in the $N$. parvum clade is interesting in that three of our isolates formed a highly supported (99\%) subclade within this clade. Similarly, in the $N$. australe clade, two relatively well-supported (71 and 82\%) subclades were formed within this clade. Pavlic et al. (21), using genealogical concordance of phylogenetic species recognition with DNA sequence data from five nuclear loci to analyze the $N$. par$v u m / N$. ribis complex on a single host, discovered that it consisted of three cryptic species occurring sympatrically, in addition to $N$. parvum. In the current study, the possibility of cryptic species within the $N$. parvum and $N$. australe clades cannot be ruled out. Further genetic analysis with additional DNA loci on a more extensive sampling of the population may help to resolve this intraspecific variation.

Climatic factors do not provide an explanation for differences in the frequencies or location of isolation of the six Botryosphaeriaceae spp. found during this study. N. australe, $N$. luteum, and $N$. parvum were found in both the northern and southern counties, with average air temperatures ranging from a low of $13.1^{\circ} \mathrm{C}$ in San Luis Obispo County to a high of $18.2^{\circ} \mathrm{C}$ in Riverside County. $F$. aesculi, D. iberica, and the unknown Neofusicoccum sp. were all isolated only from the northern counties of San Luis Obispo and Ventura. In a study of grapevine canker in California, which encompassed a large number of northern California counties as well as some southern California counties, $N$. australe (B. australis) and $N$. parvum (B. parva) were detected as far north as Sonoma County, F. aesculi (B. dothidea) as far north as Mendocino County, and N. luteum (B. lutea) only in Riverside County (36). Based on the field information from the grapevine canker study and the current study, as well as in vitro studies which showed that Botryosphaeriaceae spp. can tolerate a range of temperatures (36), it seems unlikely that climatic conditions are an important factor in the distribution of species in California. However, no definite conclusions can be made regarding species distribution on California avocado based on environmental factors without more extensive sampling accompanied by detailed environmental data.

As high-density planting becomes more frequent in California avocado groves, management strategies must be developed to protect pruning wounds from invasion by canker-causing pathogens. Currently, there are no effective fungicides used by growers to prevent infection of pruning wounds on avocado trees. Preliminary in vitro studies (V. McDonald, unpublished) have shown there are chemicals on the market that are effective against Botryosphaeriaceae and Phomopsis spp. Studies designed to evaluate the most effective fungicides to protect pruning wounds in the field are now underway.

\section{Acknowledgments}

We thank the California Avocado Commission and its members for funding and supporting this research; G. Douhan, M. Stanghellini, T. Adesemoye, and P. Rolshausen for their review of this manuscript; and S. Lynch, L. Yeung, and T. Cheung for their assistance in the lab.

\section{Literature Cited}

1. Adesemoye, A. O., and Eskalen, A. 2011. First report of Spencermartinsia viticola, Neofusicoccum australe, and $N$. parvum causing branch canker of citrus in California. Plant Dis. 95:770-770.

2. Anonymous. 2008-2009. Industry Statistical Data. California Avocado Commission. http://www.californiaavocadogrowers.com/industry-statisticaldata/.

3. Cenis, J. L. 1992. Rapid extraction of fungal DNA for PCR amplification. Nucleic Acids Res. 20:2380-2380.

4. Crous, P. W., and Palm, M. E. 1999. Reassessment of the anamorph genera Botryodiplodia, Dothiorella and Fusicoccum. Sydowia 51:167-175.

5. Crous, P. W., Slippers, B., Wingfield, M. J., Rheeder, J., Marasas, W. F. O. Philips, A. J. L., Alves, A., Burgess, T., Barber, P., and Groenwald, J. Z. 2006. Phylogenetic lineages in the Botryosphaeriaceae. Stud. Mycol 55:235-253.

6. Denman, S., Crous, P. W., Groenwald, J. Z., Slippers, B., Wingfield, B. D., and Wingfield, M. J. 2003. Circumscription of Botryosphaeria species associated with Proteaceae based on morphology and DNA sequence data. Mycologia 95:294-307.

7. Denman, S., Crous, P. W., Taylor, J. E., Kang, J. C., Pascoe, I., and Wingfield, M. J. 2000. An overview of the taxonomic history of Botryosphaeria, and a re-evaluation of its anamorphs based on morphology and ITS rDNA phylogeny. Stud. Mycol. 45:129-140.

8. Espinoza, J. G., Briceno, E. X., Chavez, E. R., Urbez-Torres, J. R., and Latorre, B. A. 2009. Neofusicoccum spp. associated with stem canker and dieback of blueberry in Chile. Plant Dis. 93:1187-1194.

9. Farr, D. F., and Rossman, A. Y. Fungal Databases. Systematic Mycology and Microbiology Laboratory, U.S. Dep. Agric., Agric. Res. Serv. http://nt ars-grin.gov/fungaldatabases/.

10. Flowers, J., Nuckles, E., Hartman, J., and Vaillancourt, L. 2001. Latent infection of Austrian and Scots pine tissues by Sphaeropsis sapinea. Plant Dis. 85:1107-1112.

11. Glass, N., and Donaldson, G. 1995. Development of primer sets designed for use with the PCR to amplify conserved genes from filamentous ascomycetes. Appl. Environ. Microbiol. 61:1323-1330.

12. Halma, F. F., and Zentmyer, G. A. 1953. Relative susceptibility of Guatemalan and Mexican avocado varieties to Dothiorella canker. Calif. Avocado Soc. Yearb. 38:156-158.

13. Hofshi, R. 1999. High-density avocado planting — an argument for replanting trees. Subtrop. Fruit News 7:9-12.

14. Hofshi, R. 2004. Beyond yield: re-engineering the avocado. In: 2nd Semin Int. Paltos. Soc. Gardiazabal y Magdahl Ltda. Quillota, Chile.

15. Horne, W. T. 1934. Avocado Diseases in California. University of California, Berkeley. 
16. Inderbitzin, P., Bostock, R. M., Trouillas, F. P., and Michailides, T. J. 2010. A six locus phylogeny reveals high species diversity in Botryosphaeriaceae from California almond. Mycologia 102:1350-1368.

17. Lazzizera, C., Frisullo, S., Alves, A., and Phillips, A. J. L. 2008. Morphology, phylogeny and pathogenicity of Botryosphaeria and Neofusicoccum species associated with drupe rot of olives in southern Italy. Plant Pathol. 57:948-956.

18. Maddison, D., and Maddison, W. 2001. MacClade 4: Analysis of Phylogeny and Character Evolution, Version 4.08. Sinauer Associates, Inc., Sunderland, MA.

19. McDonald, V., Lynch, S., and Eskalen, A. 2009. First report of Neofusicoccum australe, N. luteum, and N. parvum associated with avocado branch canker in California. Plant Dis. 93:967-967.

20. Menge, J., and Ploetz, R. C. 2003. Diseases of avocado. Pages 35-71 in: Diseases of Tropical Fruit Crops, R. C. Ploetz, ed. CABI Publishing.

21. Pavlic, D., Slippers, B., Coutinho, T. A., and Wingfield, M. J. 2009. Multiple gene genealogies and phenotypic data reveal cryptic species of the Botryosphaeriaceae: a case study on the Neofusicoccum parvum/N. ribis complex. Mol. Phylogenet. Evol. 51:259-268.

22. Pennycook, S. R., and Samuels, G. J. 1985. Botryosphaeria and Fusicoccum species associated with ripe fruit rot of Actinidia deliciosa (Kiwifruit) in New Zealand. Mycotaxon 24:445-458.

23. Phillips, A. J. L. 2002. Botryosphaeria species associated with diseases of grapevines in Portugal. Phytopathol. Mediterr. 41:3-18

24. Phillips, A. J. L., Alves, A., Correia, A., and Luque, J. 2005. Two new species of Botryosphaeria with brown, 1-septate ascospores and Dothiorella anamorphs. Mycologia 97:513-529.

25. Phillips, A. J. L., Alves, A., Pennycook, S. R., Johnston, P. R., Ramaley, A., Akulov, A., and Crous, P. W. 2008. Resolving the phylogenetic and taxonomic status of dark-spored teleomorph genera in the Botryosphaeriaceae. Persoonia 21:29-55.

26. Pitt, W. M., Huang, R., Steel, C. C., and Savocchia, S. 2010. Identification, distribution and current taxonomy of Botryosphaeriaceae species associated with grapevine decline in New South Wales and South Australia. Aust. J. Grape Wine Res. 16:258-271.

27. Sanchez, M. E., Venegas, J., Romero, M. A., Phillips, A. J. L., and Trapero, A. 2003. Botryosphaeria and related taxa causing oak canker in southwest- ern Spain. Plant Dis. 87:1515-1521.

28. Slippers, B., Crous, P. W., Denman, S., Coutinho, T. A., Wingfield, B. D., and Wingfield, M. J. 2004. Combined multiple gene genealogies and phenotypic characters differentiate several species previously identified as Botryosphaeria dothidea. Mycologia 96:83-101.

29. Slippers, B., Fourie, G., Crous, P. W., Coutinho, T. A., Wingfield, B. D., an Wingfield, M. J. 2004. Multiple gene sequences delimit Botryosphaeria australis sp. nov. from B. lutea. Mycologia 96:1030-1041.

30. Slippers, B., Johnson, G. I., Crous, P. W., Coutinho, T. A., Wingfield, B. D and Wingfield, M. J. 2005. Phylogenetic and morphological re-evaluation of the Botryosphaeria species causing diseases of Mangifera indica. Mycologia 97:99-110.

31. Slippers, B., Smit, W. A., Crous, P. W., Coutinho, T. A., Wingfield, B. D., and Wingfield, M. J. 2007. Taxonomy, phylogeny and identification of Botryosphaeriaceae associated with pome and stone fruit trees in South Africa and other regions of the world. Plant Pathol. 56:128-139.

32. Swofford, D. L. 2002. PAUP* Phylogenetic Analysis Using Parsimony, Version 4.0b10. Sinauer Associates, Inc., Sunderland, MA

33. Thompson, J. D., Gibson, T. J., Plewniak, F., Jeanmougin, F., and Higgins, D. G. 1997. The CLUSTAL X windows interface: flexible strategies for multiple sequence alignment aided by quality analysis tools. Nucleic Acids Res. 25:4876-4882.

34. UC IPM Online. 2010. Statewide Integrated Pest Management Program. http://www.ipm.ucdavis.edu/PMG/r8100611.html.

35. Urbez-Torres, J. R., and Gubler, W. D. 2009. Pathogenicity of Botryosphaeriaceae species isolated from grapevine cankers in California. Plant Dis. 93:584-592.

36. Urbez-Torres, J. R., Leavitt, G. M., Voegel, T. M., and Gubler, W. D. 2006 Identification and distribution of Botryosphaeria spp. associated with grapevine cankers in California. Plant Dis. 90:1490-1503.

37. White, T. J., Bruns, T., Lee, S., and Taylor, J. 1990. Amplification and direct sequencing of fungal ribosomal RNA genes for phylogenetics. Pages 315-322 in: PCR Protocols: A Guide to Methods and Applications. M. A. Innis, D. J. Gelfand, J. J. Sninsky, and T. J. White, eds. Academic Press, Inc., New York.

38. Zea-Bonilla, T., Gonzalez-Sanchez, M. A., Martin-Sanchez, P. M., and Perez-Jimenez, R. M. 2007. Avocado dieback caused by Neofusicoccum parvum in the Andalucia Region, Spain. Plant Dis. 91:1052-1052. 